\title{
RECESIJA I NJENO PREVAZILAŽENJE U USLOVIMA SAVREMENOG KAPITALIZMA
}

\section{Rezime}

Svet je u promenama, učestalim krizama i brojnim izazovima. Međunarodni odnosi postaju komplikovani. Ekonomski problemi u svetu doveli su do teške ekonomske situacije. Ekonomiju definišemo kao nauku o zakonima koji upravljaju proizvodnjom, odnosno zakonitostima funkcionisanja privrede i određene društvene strukture. Moglo bi se reći da je depresija imanentna kapitalističkom načinu proizvodnje od njegovog nastanka.

Razvoj teorije je sledilo naučnu revoluciju, a poredak u društvu se smatrao deo prirodnog sveta. Nekad religiozno tumačenje društvenih odnosa (pravedna cena), nije više sa pojavom kapitalizma zadovoljavalo zahteve trgovačkog života. Ideju o prirodnom zakonu koju su kasnije nadvaladala druga načela, koji se ubrzo pretvorio u odanost načelu korisnosti što je uticalo na podeljenost društva. Sa pojavom industrijske revolucije dolazi industrijski kapitalizam.

Dakle, prve teoretičare je zanimalo poreklo bogatstva. Postoje, međutim, i profit, kao i problem cena. S obzirom da se cene mogu nepredviđeno menjati, moralo je postojati neko načelo vrednosti o kojem one zavise. Kakva je uloga novca u privredi? Kakav je odnos između dohotka pojedinca i bogatstva društva u celini? Zatim, da li je pravedno da neke porodice žive u izuzetnoj raskoši, dok druge jedva preživljavaju? To je složeno pitanje, na koje teorija još nije dala zadovoljavajući odgovor. Takođe, pitanje efektivne potražnje, tj. da li će potražnja biti dovoljno velika kako bi se u potpunosti zaposlili svi raspoloživi resursi?

Bogatstvo naroda se povećava znanjem, iskustvom, tehnologijom, a sve to raste bogatstvom. Nova proizvodnja donosi i problem prodaje. Potražnja gotovo nikad nije dovoljno velika da bi svi mogli biti potpuno zaposleni? Da li na osnovu modela neoliberalne politike može da se ovlada ekonomskim krizama, kao da li se približivamo stabilnijem svetskom ekonomskom poretku ili se od njega udaljavamo?

Od 70. godina XX veka u svetu se dešavaju značajne ekonomske i političke, kao i tehnološke promene, praćene finansijskim i ekonomskim krizama koje su postale sve učestalije. Ekonomske krize kapitalizma nisu prošlost, jer po nekima "problemi ekonomije depresije nisu isčezli iz savremenog sveta".

Predmet ovog rada jeste pokušaj da se utvrdi kako dolazi do kriza kapitalističkih tržišnih privreda, kako ublažiti ekonomske i društvene posledice prouzrokovanih krizama, kako krizom upravljati, kao i mogućnost njihovog prevazilaženja u kontekstu svetskih dešavanja i njihovog uticaja na razvoj nacionalnih ekonomija, kao i društva u celini.

Ključne reči: ekonomija, kapital, kriza, depresija, migracije, bezbednost, održivi razvoj.

\section{UVOD}

Nakon hladnog rata, raspada real-socijalizma i pada SSSR-a svet je u ubrzanim promenama i brojnim izazovima. Posledice tog pada išle su u prilog političkoj, ideološkoj i tehnološkoj dominaciji kapitalizma koji se promenio. ${ }^{33}$ Evidentan je veliki ekonomski i tehnološko - naučni proces razvoja kapitalizma. Sile stvorene tehnološko naučnom revolucijom sada su dovoljno snažne da unište materijalne osnove ljudskog života. Same strukture ljudskog društva su ugrožene, nalaze se u velikoj krizi.

Kapitalizam je promenio sliku sveta, koji je ušao u fundamentalne promene društvenih odnosa i načina proizvodnje. Kapitalizam kao sistem društvenih odnosa stekao je hegemonijski status, odnosno "monopolistički položaj" što nije u skladu sa njegovom prirodom. Osnova kapitalizma jeste kapital odnos, tržište i konkurencija.

U svetu postoje, uslovno govoreći, dva preovlađujuća modela kapitalizma u svom nadmetanju. Prekoatlantski model zasniva se na ličnom uspehu i kratkoročnoj finansijskoj dobiti. Drugi model kontinentalno-evropski vrednuje kolektivni uspeh, konsensus i dugoročnost. Od 90 -ih g. primetan je pritisak prekoatlantskog ili neoameričkog kapitalizma na evropski kapitalizam. To je sukob dva vrednosna

\footnotetext{
${ }^{32}$ Ministarstvo unutrasnjih poslova RS.

${ }^{33}$ Osamdesetih godina 20. veka na engleskom govornom području došlo je do konzervativne revolucije u oblasti političke ekonomije pod geslom "minimalni uticaj države; sprovedena je finansijska reforma: manje poreza za bogate, ukoliko kapitalisti budu plaćali manje poreza, ekonomski rast će, uz nova tehnološka rešenja, biti snažniji i svima će doneti napredak".
} 
sistema koji imaju suprotne stavove o mestu zaposlenog u preduzeću, o položaju tržišta u društvu i o zakonitosti u međunarodnoj ekonomiji.

Krajem 20. veka u svetu se osnažuju nadnacionalne integracije, uključujući i evropske integracije, a ideja, odnosno, predstava o zajedničkoj budućnosti, postaje izazov. Svetskim razvojem upravljaju najrazvijenije zemlje i Transnacionalne kompanije sledeći svoje interese. Neki od glavnih izazova sa kojima se svet suočava u 21. veku, pored ostalih, jeste i rast stanovništva i ograničeni resursi. Stanovništvo na našoj planeti je sve brojnije, a time se pojačava pritisak na ograničene prirodne resurse. $\mathrm{Na}$ početku 20. veka svet je imao manje od 2 milijarde stanovnika, dok je krajem prošlog veka broj stanovnika bio veći od 6 milijardi. Smatra se da sredinom 21. veka, osim ako se ne dogodi neka katastrofa, "na Zemlji će živeti 9,2 milijardi ljudi, odnosno tri milijarde više nego danas" ${ }^{44}$. Dok u industrijski razvijenim zemljama broj stanovnika stagnira ili se smanjuje, dotle je u manje razvijenim zemljama evidentiran porast stanovništva.

Svet je umrežen i međupovezan visokim tehnologijama. U širem kontekstu ekonomiju definišemo kao nauku o zakonima koji upravljaju proizvodnjom i razmenom materijalnih sredstava za život ljudske zajednice, tj. kao nauku o ponašanju ljudi u korišćenju ograničenih resursa materijalnih dobara. Dakle, ekonomija kao nauka istražuje proces proizvodnje, raspodele, razmene i potrošnje u određenoj drušvenoj strukturi i međuodnos tih procesa - njihov uticaj na društvenu strukturu, i obratno, uticaj društva putem odlučivanja na te odnose.

Sa pojavom industrijske revolucije, nastankom preduzetništva, dolazi industrijski kapitalizam ${ }^{35}$. Privredne tokove karakterišu i povremene krize budući da ekonomska nauka nije adekvatno rešila problem cikličnog ekonomskog kretanja. Mada su neki naučnici i eksperti izjavljivali da su privredni ciklusi prevaziđeni, da su ekonomske krize prošlost, realnost je to demantovala. Krize u svetu posebno od 70-ih godina 20. veka postaju učestalije što prouzrokuje dublje ekonomske i društvene posledice.

Od početka proučavanje bogatstva naroda odnosilo se na proučavanje bogatstva svog naroda i mogućnosti njegovog povećanja. Delovanje raznih elemenata u privrednom sistemu određivalo se prema njihovom udelu u povećanju narodnog bogatstva. ${ }^{36}$

Od druge polovine 20. veka svet je zahvatila finansijska globalizacija. Uzrok pojave finansijsko ekonomske krize jeste u ekonomskoj postavci deregulacije i verovanju u svemogućnost tržišta. Međutim, tržišna ekonomija uz svesnu i naučno spoznatu koordinaciju je i dalje najbolji model, a sam modifikovan kapitalizam će uz određene promene, opstati uprkos posledicama svetske ekonomske krize, koje će ipak uslovljavati njegovo prilagođavanje novonastaloj situaciji (naučno-tehnički progres).

Realna privreda se i može razumeti, dok je finansijska ekonomija daleko složenija. Svet finansija rezultat je dugogodišnje ekonomske evolucije. Novac kao društveni odnos između poverioca i dužnika stvorio je banke za sve veći obim pozajmljivanja i zaduživanja. Tržišta hartija od vrednosti koje se emituju radi prikupljanja sredstava nose i velike rizike u poslovanju. Oni su najveći za imaoce, i to kako za stanovništvo, tako i za banke, budući da su one posrednici i organizatori tog tržišta.

Pored drugih prednosti, tehnologija, naučna dostignuća, moć Amerike nalazi se u monetarnoj oblasti. Nakon zaključivanja sporazuma u Bretton Woodsu 1945.g. ustanovljen je svetski monetarni i finansijski sistem u kojem dolar služi kao osnovno finansijsko sredstvo u međunarodnim transakcijama, a ostale se valute utvrđuju prema dolaru. Dolar je glavna valuta pri stvaranju rezervi centralnih banaka u većini zemalja. Za SAD to predstavlja povlašćen položaj budući da joj omogućuje da plaća, pozajmljuje i finansira troškove vlastitom valutom. Međunarodne institucije MMF (usklađuje platne bilanse) i SB (ekonomska obnova i razvoj zemalja članica) podržavaju ustanovljen sistem. Ta mogućnost u praksi ide mnogo dalje. Vojni rashodi su sve veći i mere se u milijardama dolara. Najveća je zaposlenost u proizvodnji naoružanja i vojne opreme. Komercijalizacija trgovine oružjem znači da SAD, u širenju svog uticaja, mogu u većoj meri da je povezuju sa trgovinom uopšte (nevojna), ekonomska pomoć i direktne investicije multinacionalnih kompanija. I danas su aktuelna neka mišljenja da "privatni interesi oligarhije ne samo što ne stvaraju opoziciju vojnim rashodima već potiču njihovo neprekidno povećanje" 37.

Neki su mišljenja da se kapitalizam spasao sopstvenog urušavanja u prvoj polovini 20. veka zahvaljujući ekonomskoj i vojnoj moći Sovjetskog Saveza, a da je kasniji slom, 90-ih, bio korak nazad u društvenoj kritici kapitalizma. Učenje o "neograničenom slobodnom tržištu" je diskreditovano kao opšteprihvaćeni "ekonomski neuspeh reganomike i tačerizma". Smatra se da su demografski i ekonomski pritisci na svetsko okruženje već "utrli put nepovratnoj krizi".

\footnotetext{
34 Žak Atali, Kratka istorija budućnosti, Arhipelag, Beograd, s. 11.

${ }^{35}$ Kapitalizam, pored ostalog, podrazumeva slobodno formiranje cena na tržištu i slobodno vlasništvo nad sredstvima za proizvodnju.

${ }^{36}$ Ekonomska teorija treba da pokuša da razume način na koji deluje neka privreda, da iznese predloge za njezino poboljšanje i da opravda kriterijum po kojem se vrednuje to poboljšanje. Kriterijum prema kojem se određuje ono što je poželjno uključuje i moralne i političke sudove s obzirom da ekonomija ne može biti neutralna, bez sadržaja ljudskih vrednosti. Videti: Smit, A., 1970. Istraživanje prirode i uzroka bogatstva naroda, Beograd.

${ }_{37}$ Paul A.Baran, Paul M. Sweezy, 1969. Monopolni kapital, Esej o američkom ekonomskom i društvenom poretku, Stvarnost, Zagreb, str. 193.
} 
Održivi razvoj je nespojiv sa svetskom ekonomijom zasnovanom na stalnoj potrazi za rastućim profitom koji je, po definiciji, sam sebi cilj, i takmiči se sa svima drugima na svetskom slobodnom tržištu. ${ }^{38}$ Zbog toga se smatra da sudbina čovečanstva zavisi od obnavljanja državne vlasti. Bolje obrazovanje, vladavina zakona, širenje finansijskih tržišta i stabilizacija kreditnog sistema - bili su ključni uslovi za industrijsku revoluciju. ${ }^{39}$ Zapadni finansijski model težio je da se proširi svuda po svetu, preko imperijalizma, a kasnije globalizacije. Postao je složen proces inovacija, posredovanja i integracija, uključujući i demografski faktor, a posebno napredak nauke i širenje zakonodavstva. Smatra se da je finansijski sistem "mozak ekonomije" s obzirom da deluje kao mehanizam koordinacije koji raspoređuje kapital, na najproduktivnije upotrebe. Ako se kapital pogrešno upotrebi ili uopšte ne cirkuliše, ekonomija će biti neefikasna i prema tome, ekonomski rast će biti nizak. I pored usavršenosti institucija i instrumenata, svet finansija pogađaju krize kao i ranije.

\section{POJAVA KRIZE HIPERPRODUKCIJE U KAPITALIZMU}

Privreda i društvo su neprekidno menjaju prelazeći iz nižih u više oblike života. To pre svega, uslovljava ubrzani naučno-tehnološki progres, porast broja stanovništva u svetu i težnja ljudi za bogatijim životom. Blagostanje i sam opstanak ljudi zavisi od realne ekonomije, prirodnih bogatstava i naučno tehničkog progresa.

Razvoj proizvodnih snaga i način proizvodnje uslovljavali su i značaj i ulogu trgovine. Kao posebna grana privrede, trgovina svojom aktivnošću - sajmovi, berze, elektronska trgovina i sl. uvećava proizvodnju profita u društvenim razmerama i ravnopravno sa drugim kapitalom, učestvuje u njegovom stvaranju. "Monopol kapitala postaje okov za način proizvodnje". Bogatstvo naroda u savremenom periodu uslovljeno je odnosom ljudi i funkcionisanjem dobrih institicija.

U ekonomskom smislu mogu se posmatrati glavni politički događaji savremene istorije. Velika depresija u drugoj polovini 19. veka dovela je do zaokreta od liberalizma prema protekcionizmu u Evopi. Imperijalistička suparništva za posledicu su imala izbijanje Prvog svetskog rata. Zbog lošeg upravljanja ekonomkom politikom tokom Velike depresije, unutrašnje političke i socijalne napetosti doprinelo je pojavi nacizma i fašizma u Evropi, došlo je do Drugog svetskog rata. U poslednjoj deceniji 20. veka, sa slomom komunizma i sveopštim prihvatanjem liberalizovanih tržišta, svet se kreće uzlaznom putanjom razvoja iz perioda pre 1914. godine.

Smatra se da je "diktatura privatne svojine razorila društvo. Sva moć je u rukama male grupe oligarha koju opslužuju bankari i političari. Takav sistem stvara svet bez pravde i budućnosti. Tokom vladavine kapitalizma izbila su dva svetska rata. Rat i danas pogađa razne krajeve sveta". Smatra se da je kapitalizam izgrađen na suštinskoj nepravdi ${ }^{40}$. Svi ljudski odnosi su podređeni manipulacijama na berzi.

Finansijska tržišta i drugi delovi tržišne ekonomije su u promenama vođeni tehnologijom, tržištima i moćnim korporacijama. Sve to ima negativne posledice u oblasti rada i na društvene odnose.

Cenu finansijskih kriza, neravnomerne raspodele bogatstva i društvene moći - sve većeg siromaštva, umanjene bezbednosti i skupljeg života - plaćaju uglavnom nerazvijeni, dok međunarodni kapital, trgovina i preduzetništvo uživaju u otvorenim tržištima.

Zbog toga je neophodno da bude uspostavljena ravnoteža između koristi koje donosi „novi globalizam" podržan visokim tehnologijama i zaštite od opasnosti koja on nosi sa sobom.

Činjenice ukazuju na unutrašnju i spoljnu povezanost i protivrečnost kapitala kao društvenog i istorijskog odnosa kome je suština u jedinstvu novog globalnog sistema. Nova struktura svetskog tržišta, uz nove tehnologije, zahteva konkurentski odnos zasnovan na kvalitetu roba i usluga u procesu spoljnotrgovinske razmene, uključujući $\mathrm{i}$ opštu konkurentnost pojedinih privreda u potrazi za što povoljnijom pozicijom na svetskom tržištu.

Usled tehnološke i finansijske moći u svetu, uspostavljen je institucionalni okvir u kome su značajna područja razvoja i međunarodnih transakcija u nadležnosti međunarodnih institucija, kao što su: $\mathrm{SB}, \mathrm{MMF}, \mathrm{STO}$. One menjaju uslove pristupa međunarodnom tržištu roba, usluga i kapitala ali i redefinišu klasični nacionalni suverenitet država u oblasti ekonomske, razvojne i spoljnotrgovinske razmene. Takođe, one nisu primereno odreagovale na globalnu krizu. ${ }^{41}$ Neka istraživanja su pokazala da nema naučne osnove za pretpostavku o efikasnosti samog tržišta. Tržište jeste obezbeđivalo podsticaje, ali

\footnotetext{
${ }^{38}$ Videti: Ilić, B; Praća, N. Održivi razvoj u uslovima informacionih tehnologija, Beograd.

${ }^{39}$ North, Douglass C., 1990. Institutions, Institutional Change, and Economic Performance, New York.

${ }^{40}$ Bogatstvo je u rukama malog broja ljudi. "Tokom krize jedan odsto ljudi nastavilo je da povećava profit, a ostalih 99 odsto bilo je na gubitku. Jedan odsto ljudi poseduje 45 odsto svetskog bogatstva, a 10 odsto stanovnika raspolaže s 86 odsto ukupnog bogatstva. Nejedenakost je ogromna - ne samo u bogatstvu, veći u moći. Politika bogatih zemalja svodi se na odbranu ličnih povlastica. Ne biraju sredstva - ako treba, ratuju. Svet nije samo nepravedan, već i nestabilan. ..." Alen Badju (Alain Badiou), Politika, 23.11.2014.

41 "Međunarodne institucije zadužene za očuvanje stabilnosti globalnog ekonomskog sistema nisu uspele da spreče krizu. ...one nisu sposobne da osmisle neophodnu koordinisanu akciju da je prevaziđu." Džozef E. Stiglic, Amerika, slobodna tržišta i slom svetske privrede - Slobodan pad, Akademska knjiga, Novi Sad, 2013. s. 243.
} 
neuspesi tržišta bili su prožimajući i postojala je stalno prisutna razlika između društvenih i privatnih dobitaka. 42

Od sedamdesetih godina XX veka svet je u promenama i nalazi se pred velikim izazovima. Visoke informaciono-komunikacione tehnologije su povezale svet. Međunarodni odnosi postaju sve složeniji, pre svega, zbog moći visokorazvijenog kapitalističkog načina proizvodnje. Važnost novih industrijskih i tehnoloških pomaka daleko premašuje neposredne koristi. ${ }^{43}$ Promene u proizvodnoj tehnici usled pronalazaka i primene novih izvora energije i novih proizvodnih pogona („mašina radilica, vodena para“) dovelo je do prve industrijske revolucije. To je doprinelo razvoju kapitalističkog načina proizvodnje. Ubrzano širenje tržišta zahtevalo je velike količine proizvoda, a međusobna konkurencija je pritiskala kapitaliste da pronađu način koji će omogućiti smanjenje proizvodnih troškova, povećanje produktivnosti rada i dobijanje relativnog viška vrednosti. Industrijska revolucija (prelazak na mašinsku proizvodnju) prvo je zahvatila englesku tekstilnu industriju, koja je u to vreme predstavljala preko $60 \%$ engleskog izvoza, a zatim i druge zapadno evropske zemlje. Ona je ubrzala razvoj kapitalističkog načina proizvodnje i pojačala eksploataciju, posebno dobijanjem relativnog viška vrednosti. Istovremeno je ubrzala proces jačanja i zaoštravanja suprotnosti kapitalističkog privrednog sistema i donela sa sobom niz novih socijalnih i političkih problema. Takođe, počelo je razdoblje periodičnih ekonomskih kriza hiperprodukcije i povremene stagnacije privredne aktivnosti. Nakon određenog vremena usledile su druga i treća industrijska revolucija. Nova otkrića u drugoj polovini 19. veka pripremila su uslove za veliki napredak u razvoju tehnologije. Na prelazu iz 19. u 20. vek počinje druga industrijska revolucija, koja se zasniva na primeni električne energije u industriji, motora sa unutrašnjim sagorevanjem, razvoju hemijske industrije, upoteba benzinskih motora i eksplatacija nafte. Treća industrijska revolucija počinje sredinom 20 veka. Ona se temelji na mirnodopskoj primeni atomske i hidrogenske energije, čipa, biotehnologije, upotrebi sintetičkih materijala, na elektronici, automatizaciji i kompjuterizaciji proizvodnih procesa. Ova naučnotehnološka revlucija donosi proizvodne mogućnosti širih razmera, razvija veliku produktvnost ljudskog rada u oblasti materijalne proizvodnje, takođe, ona izaziva još veće i dalekosežne socijalne i političke promene u društvu. Prelaz na elektroniku i njenu praktičnu primenu doneo je tehnologiju s visokim kapitalnim, naučno-inovacionim i obrazovnim intezitetom, malom potrošnjom sirovina, malim utroškom energije u proizvodnji, te malim stepenom zagađenja prirode. Visoka tehnologija (mikroelektronika, robotizacija, automatizacija, biotehnologija, genetski inženjering, laser, itd.) donosi sasvim novi način proizvodnje, suštinski izmenjen odnos čoveka prema radu u procesu proizvodnje. $U$ naše vreme se govori o četvrtoj naučno - tehnološkoj revoluciji koju karakteriše pronalazak sunčeve energije i energije vetra kao pogonske, koja u budućnosti treba da bude alternativa primeni nafte.

Sve te naučno-tehnološke revolucije uslovljavaju promenu privredne strukture, promenu strukture zaposlenosti, organizaciju proizvodnje, međunarodnu povezanost, promenu obrazovnog sistema i sl. Dakle, to menja i ljude i prilike.

Istorija razvoja ljudskog društva pokazuje da je kriza svojstvena kapitalističkom načinu proizvodnje i da predstavlja sastavni deo ciklusa kapitalističke tržišne privrede. Temeljni problem kapitalističke reprodukcije nalazi se u oblasti makroeknomije, odnosno makrostrukture, to jest $u$ međusobnom odnosu dveju uopštenih grupa proizvodnje, tzv. odeljka I (proizvodnja sredstava za proizvodnju) i odeljka II (proizvodnja potrošnih dobara). Odeljci društvene proizvodnje uglavnom se neravnomerno razvijaju, budući da uslovi poslovanja, odnosno privređivanja nikada nisu stalni. ${ }^{44}$

\section{KRIZE HIPERPRODUKCIJE U PERIODU DRŽAVNO-MONOPOLISTIČKOG KAPITALIZMA}

U svetskoj privredi vladaju monopolske i oligopolske strukture. Monopol označava isključivo pravo ili mogućnost posedovanje neke stvari, proizvodnje ili prodaje određene robe. U svetu se pojavljuje monopolski kapitalizam, odnosno neoimperijalizam. Budući da monopol kapitala postaje prepreka za novi način proizvodnje, postavlja se pitanje: kako upravljati monopolom?

Društvena reprodukcija podrazumeva proces stalnog obnavljanja proizvodnje na istoj ili uvećanoj osnovi. Da bi se ova reprodukcija mogla normalno odvijati podrazumeva se normalni protok kapitala, uz srazmernost raspodele svih činilaca proizvodnje u svim fazama reprodukcije. Privrednu ravnotežu uspostavlja tok vrednosti, mehanizam uspostavljanja te ravnoteže je slobodno kretanje činilaca proizvodnje i seoba kapitala iz jedne grane u drugu granu.

\footnotetext{
42 Isto, s. 276.

${ }^{43}$ Ekonomski i tehnološki napredak doprineo je i širenju tržišta štampane reči. Tipografska revolucuja J. Gutenberga (Johannes Gutenberg) sredinom 15 v. pružila je knjige mnogim ljudima, kojima je ona ranije bila skupa. Širenjem pristupa pisanoj reči omogućeno je veće izlaganje ljudi novim idejama. Tako je pružen doprinos pritiscima koji su, tokom vremena, izmenili društvene odnose. Društvo i politika više nikada nisu bili kao nekada. Industrijska revolucija koja je počela u Engleskoj u 18. veku imala je veliki uticaj na društvo. Ona je ne samo revolucionisala proizvodni proces, već i način kako je čovek organizovao društvo i na koji način je vodio ratove. Ona je zauvek promenila ekonomsko i političko lice Evrope, dovela do ubrzane urbanizacije mnogih delova sveta, doprinela rastu Sjedinjeni Država, i izmenila karakter života širom planete. Danas u svetu pojavljuju se ideje da se može bez štampanja knjiga budući da su nove kominikacione tehnologije i Internet povezale ljude i pisane reči.

${ }^{44}$ Videti: Ilić, B., Praća, N., 2014. Održivi razvoj u uslovima informaciono - komunikacionih tehnologija, s. 20.
} 
U privredama sveta poznate su određene krize i poremećaji što dovodi do napuštanja ravnoteže sa svim nevoljama koje iz toga proizlaze. Poremećaji u privredi ukoliko nisu izazvani prirodnim pojavama, ratovima i sl. nastaju najčešće zbog nemogućnosti uspešne oplodnje kapitala, tj. poremećaji se javljaju u fazi razmene.

Uzroci takvih poremećaja nisu identični i najčešće dolaze zbog funkcionisanja novca kao prometnog sredstva. Isto tako uzroci mogu biti i novac kao platežno sredstvo, koji se najčešće i okrivljuje za pojavu krize hiperprodukcije. Činjenica da se mogu odgoditi kupovine, vodi najčešće nagomilavanju zaliha proizvedenih roba. Smanjivanje najamnina drugi je uzrok nedovoljnoj tražnji i potrošnji, a preko tih činioca i pojave hiperprodukcije. Do toga dolazi zbog preraspodele novostvorene vrednosti. Sve veći delovi koriste se za proširenu reprodukciju što automatski vodi rastu proizvodnje, ali isto tako i sve manjem izdvajanju sredstava namenjenih ličnoj potrošnji. Navedene pojave za posledicu imaju ogromnu proizvodnju koju ne može da prati adekvatna tražnja.

Jedna od faza privrednog ciklusa jeste i kriza. Krize hiperprodukcije karakteriše sledeće: ogromna proizvodnja roba uz sve veće smanjenje prodaje; rast nezaposlenosti, a sa njom i sve manje mogućnosti kupovine, odnosno smanjivanje kupovne moći stanovništva. Pad cena uprkos toj činjenici i dalje se nastavlja sa padom tražnje, rast kamatnih stopa, pojava stečajeva; bankrotstva i propadanja velikog broja firmi koje za sobom ostavljaju ogroman broj nezaposlenih. Slabosti i nedostaci kapitalističkog sistema ukazuju na "njegov neuspeh da obezbedi punu zaposlenost i njegova proizvoljna i nepravedna raspodela bogatstva i dohodaka." 45

Prva svetska ekonomska kriza bila je 1825. g., (izazvana, pored ostalog, "latinoameričkom dužničkom krizom") da bi posle toga svakih 10-tak godina privreda sveta ili nekih regiona padala u određenu krizu, odnosno depresiju (pad rasta proizvodnje). Velikom svetskom krizom (1929. - 1933.g.) do temelja je bila uzdrmana čitava svetska privreda, gde se verovalo da će tom krizom potonuti i kapitalistički sistem privređivanja. ${ }^{46}$

Osim shvatanja o uzrocima i pojavama kriza hiperprodukcije koje se pojavljuju svakih $10 \mathrm{~g}$., zanimljivi su i Kontratjevi ciklusi kojima se pokušava ukazati na probleme i uzroke koji se dešavaju u svetskoj ekonomiji. ${ }^{47}$ Velika ekonomska kriza 1929-33, osim po dubini i oštrini i posledicama u odnosu na druge krize, bila je prva opšta kriza sistema kapitalističkog načina proizvodnje. Tokom Velike krize najrazvijenije zemlje preduzimale su određene mere ekonomske politike. ${ }^{48}$

Uzroci krize se nalaze u samom kapitalističkom načinu proizvodnje i njemu imanentnim suprotnostima. Krize su neizbežne zbog toga što postoji suprotnost između kolektivnog karaktera proizvodnje i individualnog karaktera prisvajanja, što je i uzrok narušavanju srazmere potrebne za normalno odvijanje proširene reprodukcije. Dakle, neizbežnost ekonomskih kriza u kapitalizmu proizilazi iz same prirode tog načina proizvodnje kao njemu imanentna zakonitost. Zato je istorija razvoja kapitalizma istovetna sa istorijom ekonomskih kriza.

Privredni ciklusi nisu prevaziđeni. Sedamdesetih godina 20. veka razvijeni svet je zadesila "stagflacija", istovremeni pad privredne aktivnosti i inflacija. Usled energentskih kriza (1973. i 1979.g.), zatim 1982, 2000 i 2008. g. usledila je recesija svetske privrede, a pozicije manje razvijenih zemalja su se znatno pogoršale. Kako bi se sprečile krize hiperprodukcije u privrednim tokovima, država merama ekonomske politike utiče na privredne tokove.

\section{SAVREMENA DEPRESIJA SVETSKE PRIVREDE I NJENJE POSLEDICE}

Velika recesija koja je počela 2008. godine u SAD pogodila je ljude u SAD i šrom sveta. Nove inovacije omogućile su bankama da sakriju veliki deo svojih nestručno odobrenih kredita, izmeštajući ih iz bilansa stanja, te da na taj način povećaju svoj efektivni leveridž - što je imalo za posledicu da se naduva veći balon?, a pustoš, koju je uzrokovalo njegovo pucanje, poveća. Smatra se da kriza ne uništava imovinu privrede. Možda bankrotiraju banke. Možda bankrotiraju mnoge firme i domaćinstva. Ali realne efektive biće više nego što je bilo ranije - biće više istih zgrada, fabrika i ljudi; istog ljudskog, fizičkog i prirodnog kapitala. Ono što se dešava u krizi jeste da "erodiraju poverenje i nada", da institucionalni materijal društva slabi kada banke i firme bankrotiraju ili se približe bankrotu i da tržišna privreda pomeša

\footnotetext{
${ }^{45}$ Keynes, M. J. 1956. Opšta teorija zaposlenosti, kamate i novca, Kultura, Beograd, s. 394.

46 Kejns je sa svojom teorijom doprineo unapređivanju tržišta a ne njegovim uništavanjem, što su neki ekonomisti predviđali, u mnogome doprinosi ne samo kod prevazilaženja te krize već i kod njenih ublažavanja u budućnosti.

${ }^{47}$ Prema Kontratjevim ciklusima svetska privreda se kreće ciklično, a jedan ciklus traje 50 godina.

48 "Cilj je ekonomske politike adekvatnost a ne zasićenost tražnje, a ovakav cilj ne može se postići bez državne pomoći. Adekvatnost tražnje će osigurati visoki stepen proizvodnosti rada jer ona povećava kapacitet proizvodnje niskim troškovima po jedinici, i može obezbediti nova finansijska sredstva za unapređenje nauke. Osim toga, visok nivo zaposlenosti, pratilac adekvatne tražnje, rešiće mnoge probleme nesigurnosti.“ Videti u: Seymour E. Harris, 1954. Spasavanje američkog kapitalizma, Kultura, Beograd, s. 13.

Balon predstavlja sinonim za veliko i brzo povećanje cena imovine/aktiva, najčešće uzrokovano špekulacijama i entuzijazmom, a ne njihovom suštinski povećanom vrednošću, nakon čega sledi veliki pad cena imovine/aktiva.
} 
vlasnička prava. Nije uvek jasno ko poseduje i kontroliše posebne aktive, na pr. u redovnom postupku bankrota nije jasan prenos vlasništva sa akcionara na investitore u obveznice.

U predkriznom periodu, resursi se iscrpljuju - na primer, novac se ulaže pre u izgradnju kuća nego što se koristi produktivno. Ključno pitanje je kako će se resursi koristiti nakon što balon pukne, tj. kada se pojavi najveći deo gubitaka, kada se resursi ne koriste efikasno i u punom kapacitetu i kada se nezaposlenost poveća. Ovo su propusti realnog tržišta i ne mogu se izbeći ako na svoje mesto dolaze prave politike. Ono što skreće pažnju jeste koliko često ne dođu prave politike i koliko često se mešaju gubici nastali tokom formiranja balona sa gubicima koji se stvaraju nakon njegovog pucanja.

Dobar program podsticaja treba da istakne određene principe, npr.: brzina; efikasnost; usmerenost na dugoročne probleme u državi; usmerenost na investiranje; pravičnost; hitnim potrebama koje je stvorila kriza; usmeravanje podsticaja u sektore u kojima se ukidaju radna mesta. Šta je urađeno i šta bi trebalo uraditi. Nastale su protivrečnosti. Konzervativci su bili protiv budžetskog deficita, a kejnzijanci su smatrali da preko budžetskog deficita vlada treba da stimuliše privredu. SAD i svet se suočavaju sa tri izazova: oživeti održivu agregatnu tražnju i svuda osigurati punu zaposlenost, rekonstruisati finansijski sistem na način da izvršava funkcije, a ne da nesmotreno preuzima rizik kao pre krize, rekonstruisati svetsku privredu, npr. da se svuda odraze promene komparativnih prednosti i promene u tehnologiji.

Problemi su nastali u finansijskom sektoru koji je bio "u srcu oluje". Smatra se da će "nečasno postupanje prilikom odobravanja hipotekarnih kredita u SAD biti upamćeno kao velika prevara s početka dvadeset prvog veka"49. "Ukupni napori da se spasi bankarski sistem bili su toliko loši delimično i zato što su oni koji su bili odgovorni za nered, zagovornici deregulacije, neuspešni kontrolori, investicioni bankari, zaduženi da ga otklone". 50

Od sedamdesetih godina XX veka svetska privreda ulazi u novu fazu razvoja i III naučno tehnološka revolucija. U najrazvijenijoj ekonomiji sveta, neregulisano tržište preplavljeno likvidnošću i niskim kamatnim stopama, brz rast cena balon nekretnina na globalnom nivou i naglo povećanje u odobravanju bankarskih kredita nelikvidnim dužnicima vodilo je krizi uz to i američki fiskalni i trgovinski deficit i saglasno tome akumulacija ogromnih dolarskih rezervi u Kini - neuravnotežene globalne privrede, samo je doprinelo još težoj situaciji i krizi koja se proširila na ceo svet.

Liberalizacija i deregulacija nose rizike. Sa krizom 2008.g. došlo je do kolapsa bankarskog sistem u najrazvijenim kapitalističkim tržišnim privredana. Island je bio prva razvijena država koja se posle relativo dužeg perioda obratila za pomoć MMF-u. Banke Islanda, poput drugih banaka, preuzele su visoki leveridž i visoke rizike. ${ }^{51}$ Kada su finansijska tržišta shvatila rizik i počela da povlače novac, ove banke namamile su novac depozitara iz Velike Britanije i Holandije nudeći im proizvod "islandski štedni račun" sa visokim prinosima. Opšte mišljenje o snažnom odgovoru evropskih vlada bilo da je Island, otkrio, učinio vidljivom fundamentalnu grešku u Evropskoj integraciji: "jedinstveno tržište" znači da bilo koja evropska banka može da posluje u bilo kojoj zemlji; utvrđeno je da je odgovornost za regulativu na matičnoj zemlji; ali kada matična zemlja pogrešno uradi posao, građani u drugim zemljama mogu da izgube milijarde.

Polako se kruni evropska država blagostanja. Budućnost države blagostanja, tekovine na koju su narodi Evrope bili ponosni jer je uvek garantovala život dostojan čoveka, pa i u slučaju nezaposlenosti, starosti i bolesti, nikada nije bila neizvesnija. Kriza je učinila svoje širom Evrope, a "država blagostanja", povlači se pred proameričkom politikom u oblasti rada. Liberalizacija tržišta rada dovela je do toga da je radnik sve manje zaštićen. Mnoge evropske države, a naročito one na jugu ${ }^{52}$ (Španija, Irska, Portugalija, Grčka) koje su najviše pogođene krizom počele su sve manje da štite radnike i da umanjuju cenu rada. To je način da se bude konkurentan i da se poveća zaposlenost. lako se evropski odgovor na krizu fokusirao na smanjenje budžetskih troškova, izvesno je da će ubuduće morati da ga prati i "erozija" zaštite radnika. Poslednjih godina u evropskim državama prekoatlantski model počeo je da dobija primat. Kriza je oborila proizvodnju, samim tim smanjila dohotke i ugrozila državu blagostanja. Sigurnost radnog mesta se smanjuje, to je trend u mnogim državama u Evropi. Međutim, paradoksalno je da je i u samoj Americi država počela da spasava pojedine banke i kompanije. Smatra se da živimo u postindustrijskom vremenu. Pokazalo se da je model države blagostanja iz osamdesetih i devedesetih godina XX veka neodrživ. To je dovelo do rasta nacionalnih dugova i manjih mogućnosti da standard i dalje raste. lako nije Velika depresija, stanje je i dalje teško, poput nekih razmišljanja iz tridesetih godina XX veka: "Hronično stanje nenormalno niske aktivnosti tokom dužeg vremenskog perioda, bez ikakve izražene tendencije bilo ka oporavku ili ka potpunom kolapsu"53.

\footnotetext{
${ }^{49}$ Džozef E. Stiglic, Amerika, slobodna tržišta i slom svetske privrede - Slobodan pad, Akademska knjiga, Novi Sad, 2013. s. 107.

${ }^{50}$ Džozef E. Stiglic, op.cit., s. 180.

${ }^{51}$ Džozef E. Stiglic, op.cit., s. 53-54.

52 Španija je produžila rad na određeno vreme i omogućila poslodavcima da radnike drže u tom položaju čak četiri godine. Irska i Portugalija su zamrzle minimalne zarade, dok in je Grčka umanjila gotovo za četvrtinu.

${ }^{53}$ Keynes, M. J. 1956. Opšta teorija zaposlenosti, kamate i novca, Kultura, Beograd.
} 
U svetu je uspostavljen novi kapitalistički poredak. Bavljenje krizom i sprečavanje budućih kriza jeste političko koliko i ekonomsko pitanje. Ako mislimo da ponovo uspostavimo održivi napredak, potreban nam je novi skup duštvenih ugovora zasnovanih na poverenju između građana i države, između ove generacije i budućih generacija. ${ }^{54}$

Neuspešna je globalna reakcija na krizu. Globalna zajednica shvatila je da je ceo svet bio "u tome" zajedno: Amerika je povukla dole ostale zemlje, ali slabosti ostatka sveta prete da ugroze američku sposobnost da se oporavi. Čak i u globalizovanom svetu formulisanje politika odvija se na nacionalnom nivou. Svaka država procenjuje koristi i troškove svojih aktivnosti, nezavisno od njihovih efekata na ostatak sveta. ${ }^{55} \mathrm{U}$ ovoj krizi, prema nekim teoretičarima, deregulacija je imala ključnu ulogu. Kako bi se sprečila nova kriza i povratilo poverenje u banke i druge finansijske institucije, smatra se da su potreban nova pravila.

\section{ZAKLJUČAK}

Iz navedenog proizilazi da depresija, nezaposlenost i inflacija potresaju savremeni svet, te je osnovni zadatak ekonomske nauke kako da se prevaziđu te najveće boljke savremene privrede i društva. Nažalost o tim problemima postoje i najveće nesuglasice među ekonomistima. Tome ima više razloga. Jedni smatraju da se to može rešiti različitim ekonometrijskim i sl. modelima i željama, drugi smatraju da treba izučavati konkretnu privrednu praksu, treći smatraju da treba primenjivati puteve razvoja (imitacija) visokorazvijenih zemalja i sl. Nažalost, život se neda kalupiti ni u kakve modele, obrasce, šeme i sl., niti trpi imitaciju. On se menja zakonito kao svaki drugi biljni i životinjski organizam, na različite načine i u različito vreme. Na to danas najviše utiče ubzaniji razvoj nauke i tehnike. Zadatak sadašnje generacije jeste u tome da istraži uslove i mogućnosti za konstituisanje novog društva koje će obezbeđivati prosperitet i svake nacije i svakog pojedinca. U tom smislu i poznati nobelovac Džozef Stiglic konstatuje: "Jednostavno teza za ovo poglavlje je da bi u ovom trenutku trebalo da podvučemo crtu, dobro promislimo o tome kakvo društvo želimo da imamo i zapitamo se da li gradimo privredu koja nam pomaže da ostvarimo naše težnje"... Nešto kasnije od toga Štiglic precizira: "Najvažnije od svega, sada imamo priliku da stvorimo novo društvo (podvukao B.I.) u kome će svaki pojedinac biti u stanju da ostvari svoje težnje i svoj potencijal, u kome će građani ostvarivati zajedničke ideale i vrednosti, u kome ćemo stvarati zajednicu koja se prema našoj planeti odnosi sa neophodnim poštovanjem. To su prilike. Stvarna opasnost leži u tome da ih nećemo iskoristiti. ${ }^{56}$

U procesu stvaranja novog društva veliku pomoć može da pruži najnovija knjiga poznatog francuskog autora Toma Piketija "Kapital u XXI veku" izdata kod nas 2015. godine u Novom Sadu koja je postala besteler u svetu i kod nas. Piketi je dugogodišnjom analizom istorijskih, filozofskih, statističkih i sličnih podataka utvrdio da stopa prinosa na kapital raste mnogo brže od stope privrednog rasta i završava stalnim uvećanjem ekonomske nejednakosti. Iz toga proizilazi da se mnogo brže razvijaju bogate zemlje (imaju veći kapital), kao i pojedinci u svim zemljama koji poseduju veliki kapital. To dovodi do neravnoteže u privredi i društvu, do produženje jaza u nivou bogatstva, pa i do kriza i depresija u zemljama i svetu u celini. Otuda Piketi zaključuje. "Bez stvarnog prava na intervenciju u današnju odluku (poput prava glasa radnika u upravnim odborima), transparentnost ničemu ne služi. Informisanost može da bude oslonac poreskih i demokratskih institucija; ona nije samo sebi svrha. Da bi demokratija jednog dana preuzela kontrolu nad kapitalizmom, (podvukao B.I.) najpre je potrebno poći od načela da se konkretne forme demokratije i kapitala tek moraju pronaći." 57

$\mathrm{Na}$ ovom putu već se ostvaruju novi procesi formiranjem BRIKS-a, evro-azijske integracije kao pandan Evropskoj uniji i osnivanjem Razvojne banke BRIKS-a kao pandanu MMF i Svetskoj banci sa sedištem u Pekingu gde će rezervna valuta postati kineski juan. Ova banka je osnovana sa velikim kapitalom, ima već preko 20 zemalja članica, a kao kandidati konkurišu neke Skandinavske zemlje, kao i vodeće članice EU, kao Nemačka i Francuska, Italija, Velika Britanija i druge. Ocenjuje se da će Kina za jednu deceniju postati najmoćnija zemlja sveta.

S obzirom na imanentnost depresije u kapitalističkoj tržišnoj privredi, uslovi za njeno prevazilaženje nalaze se u samom načinu proizvodnje i društvenim odnosima. Menjanje društvenih odnosa menja se sam način proizvodnje što vodi novom društvu - društvo socijalne saglasnosti. Kakav finansijski sistem želimo na kraju. Izvesno je da će ova kriza dovesti do promena. Prilika je da se izgradi novo društvo u kome će svaki pojedinac biti u stanju da ostvari svoje težnje i svoj potencijal. Međutim, opasnost leži u tome da in nećemo iskoristiti. Međunarodno ekonomski i drugi odnosi bi trebao da funkcionošu na osnovu Povelje UN i u okvirima UN. Pridržavanje zahteva Povelje, a takođe merama poverenja i međunarodne saradnje u svim aspektima - ekonomskim, političkim, humanitarnim i drugim,

\footnotetext{
${ }^{54}$ Džozef E. Stiglic, Slobodan pad, Akademska knjiga, Novi Sad, 2013, s. 242.

${ }^{55}$ Džozef E. Stiglic, op.cit., s. 245.

${ }^{56}$ Džosef E. Stiglic, Amerika, slobodna tržišta i slom svetske privrede - Slobodan pad, prevod, Novi Sad, 2013. g., str. 307 i 328.

${ }^{57}$ Toma Piketi, Kapital u XXI veku, Novi Sad, 2015. g., str. 624.
} 
obezbediće mir i razvoj u svetu. Ekonomska sigurnost država je neophodan uslov boljih međunarodnih ekonomskih odnosa.

\section{LITERATURA}

1. Atali, Žak, 2010. Kratka istorija budućnosti, Arhipelag, Beograd.

2. Bergston, C. F. 2009. „Needed: A Global Response to the Global Economic and Financial Crisis“, Peterson Institut for International Economics.

3. Commission of the European Communities 2008. European Competitiveness Report 2008. Brussels

4. Davies, K. "While global FDI falls, China's outward FDI doubles," Columbia FDI perspectives, No.5, May 26, 2009.

5. Dolman, Antoni J. Ettinger, Jan Van, 1979. Partneri u sutrašnjici, Globus, Zagreb.

6. European Bank for Reconstruction \& Development 2008. Transition report 2008. London.

7. Evropska unija i Srbija - od tranzicije do pridruživanja, 2012. NDES i Ekonomski fakultet.

8. Friedman, Milton, 1973, Teorija novca i monetarna politika, IP „Rad“, Beograd.

9. Ilić, B., 2003. Informatičko društvo i nova ekonomija, Beograd.

10. llić, B., 1995. Aktualna pitanja savremene političke ekonomije, Savremena administracija, Beograd.

11. Ilić, B., Praća N., 2014. Održivi razvoj u uslovima informaciono komunikacionih tehnologija, Apollo, Beograd.

12. International Monetary Fund 2009. Global financial stability report. April

13. Keynes, M. J. 1956. Opšta teorija zaposlenosti, kamate i novca, Kultura, Beograd.

14. Kovačević, Mlađen, Katastrofalne posledice najveće zablude ekonomske nauke neoliberalizma, u: Globalna kriza i ekonomska nauka, Neoliberalizam i alternative, 2012, Zbornik radova, Ekonomski fakultet u Beogradu.

15. Kostas Duzinas, 2012. Ljudska prava i imperija - Politička filozofija kosmopolitizma, Službeni glasnik, Beograd.

16. Krugman, Pol, 2008. Povratak ekonomije depresije i svetska kriza 2008, IP Heliks, Beograd.

17. Krugman, Pol, 2012. Okončajte ovu depresiju. odmah!, Heliks, Smederevo, Beograd.

18. Kisindžer, Henri, 2014. "Svetski poredak: Razmišljanja povodom karaktera nacija i hoda istorije" (World Order: Reflections on the Character of Nations and the Course of History)

19. Lardy, N.R. "China's Role in the Origin and Response to the Global Recession," Speeches, Testimony, Papers, Peterson Institute for International Economics 12/ 02/2009.

20. Milanović, B., "Bogati i siromašni - kratka istorija globalne nejednakosti" (The Haves and Have Nots. A Brief and Idiosyncratic history of global inequality, Basic Books, New York, 2011.)

21. Naj, Džosef S., 2010. Budućnost moći, Arhipelag, Beograd.

22. Noam Čomski, 2013. Moć i teror, Vulkan, Beograd

23. North, Douglass C., 1990. Institutions, Institutional Change, and Economic Performance, New York

24. Piketi, Toma, 2015. Kapital u XXI veku, Novi Sad, 2015.

25. Reinert, Erik S., 2006. Globalna ekonomija, Čigoja, Beograd.

26. Soto, Hernando de, 2000. The Mystery of Capital, New York: Basic Books.

27. Stiglitc, Džozef E., 2013. Amerika, slobodna tržišta i slom svetske privrede - Slobodan pad, prevod, Novi Sad.

28. Stiglitz, J.E., 2012. Cena nejednakosti: kako današnje podeljeno društvo ugrožava našu budućnost, DC. Vashington.

29. Smit, Adam, 1970. Istraživanje prirode i uzroka bogatstva naroda, Kultura, Beograd.

30. Seymour E. Harris, 1954. Spasavanje američkog kapitalizma, Kultura, Beograd.

31. Sol, R. Dž., 2011. Propast globalizma i preoblikovanje sveta, Arhipelag, Beograd.

\section{Abstract}

The world is changing, the frequent crises and numerous challenges. International relationships become complicated. Economic problems in the world have led to the difficult economic situation. Economics is defined as the science of the laws that govern the production, or the laws of functioning of the economy and certain social structures. You could say that depression is immanent capitalist mode of production

since

its

inception.

The development of the theory of the scientific revolution followed, and order in society are 
considered part of the natural world. Once a religious interpretation of social relationships (fair price), is no longer with the emergence of capitalism satisfy the demands of commercial life. The idea of natural law which was later nadvaladala other principles, which soon turned into a commitment to the principle of utility which resulted in the division of society. With the advent of the industrial revolution came industrial capitalism.

So, the first theorists wondered origin of wealth. There are, however, and profits, as well as the issue price. Given that the prices may change unpredictably, there had to be some principle values on which they depend. What is the role of money in the economy? What is the relationship between an individual's income and wealth of society as a whole? Then, is it fair that some families live in extreme luxury, while others barely survive? This is a complex question to which theory has not yet given a satisfactory answer. Also, the question of effective demand, ie. whether demand will be large enough to fully employ all available resources?

The wealth of nations is increasing the knowledge, experience, technology, and all this growing wealth. New production is also the matter of sales. Demand is almost never large enough to allow everyone to be fully employed? Whether based on the model of neoliberal policies can master the economic crisis, as well as whether približivamo more stable global economic order or move away from it?

From the 70th years of XX century in the world occur significant economic and political as well as technological changes, followed by the financial and economic crises have become more frequent. The economic crisis of capitalism is not past, because according to some "problems of depression economics have not disappeared from the modern world."

The subject of this paper is an attempt to determine how to come up with a crisis of capitalist market economy, how to mitigate the economic and social consequences caused by the crisis, to manage the crisis and the possibility of overcoming them in the context of world events and their impact on the development of national economy and society in whole.

Keywords: economy, capital, crisis, depression, migration, security, sustainable development. 